\title{
Nuclear Receptor Corepressor 2
}

National Cancer Institute

\section{Source}

National Cancer Institute. Nuclear Receptor Corepressor 2. NCI Thesaurus. Code C19891.

Nuclear receptor corepressor 2 (2525 aa, $\sim 275 \mathrm{kDa}$ ) is encoded by the human NCOR2 gene. This protein plays a role in both chromatin remodeling and the repression of hormone receptor-mediated transcription. 